\title{
QUANTITATIVE VARIATION OF NUCLEAR DNA IN GENUS AEGILOPS1)
}

\author{
YOSHIHIKO FURUTA
}

Faculty of Agriculture, Gifu University, Gifu 504

Received December 25, 1974

Genus Aegilops that is native in the Near and Middle East comprises nine diploid $(\mathrm{n}=7)$, nine tetraploid $(\mathrm{n}=14)$ and four hexaploid $(\mathrm{n}=21)$ species and is closely related to wheat, one of the most important crops. Ae. squarrosa $(\mathrm{n}=7)$ is known to be the donor of the $\mathrm{D}$ genome to common wheat (Genome: $\mathrm{ABD}$ ), and Ae. speltoides is presumed to have given the B genome to Emmer wheat. Some other species of this genus have been studied intensively in relation to the origin of polyploid wheat and evaluated as the source of the genes desirable for wheat breeding (Sears 1956).

On the other hand, many investigations with respect to taxonomy and phylogeny of this genus have been also made from various viewpoints. First of all, it was classified systematically into nine sections including 20 species by Zhukovsky (1928) and into two subgenera and six sections including 22 species by Eig (1929), and they showed geographical distribution of these species. Senjaninova-Korczagina (1932) and Chennaveeraiah (1960) analysed karyotypes of all species involved and discussed their phylogeny. Kihara (1954) classified Aegilops species into six sections by means of genome analysis and discussed species relationships of nine diploids and evolution of polyploids. Zohary and Feldman (1962) emphasized the role of introgressive hybridization on speciation of tetraploids in Aegilops. Recently, Nakai and Tsunewaki (1971) and Nakai (1973) discussed species relationship of Aegilops and Triticum based on polymorphism of esterase and acid phosphatase isozymes.

The author performed the present study to characterize each species of Aegilops with regard to DNA content per nucleus.

\section{MATERIALS AND METHODS}

Species and varieties used in the present study are listed in Table 1, along with their chromosome numbers and genome constitutions presented by Kihara (1954) and Kihara and Tanaka (1970).

Young anthers at the quartet stage were fixed in Farmer's fluid for three days, transferred through a descending series to $75 \%$ ethanol and then stored in a refrigerator until used. Ae. speltoides, Ae. variabilis and Ae. triaristata $6 \mathrm{x}$ were selected as the standard species of diploid, tetraploid and hexaploid, respectively. Comparisons were

1) Contribution from the Laboratory of Genetics and Plant Breeding, Faculty of Agriculture, Gifu University, No. 45. 
Table 1. Chromosome number, genome constitution and DNA content per nucleus of Aegilops species used in the present study

\begin{tabular}{|c|c|c|c|c|c|}
\hline \multirow{2}{*}{ Section } & \multirow{2}{*}{ Species } & \multirow{2}{*}{$2 n$} & \multirow{2}{*}{ Genome } & \multicolumn{2}{|c|}{ DNA content/Nucleus } \\
\hline & & & & $\bar{X} \pm S . E$. & Ratio* \\
\hline \multirow[t]{11}{*}{ Polyeides } & Ae. umbellulata Zhuk. & 14 & $\mathrm{Cu}^{u}$ & $176 \pm 3$ & 1.27 \\
\hline & Ae. ovata $\mathrm{L}$ & 28 & $\mathrm{Cu}^{\mathrm{u}} \mathrm{M}^{\circ}$ & $321 \pm 7$ & 2.31 \\
\hline & Ae. columnaris Zhuk. & 28 & $\mathrm{Cu}^{\mathrm{u}} \mathrm{Mc}^{\mathrm{c}}$ & $365 \pm 7$ & 2.23 \\
\hline & Ae. biuncialis Vis. & 28 & $\mathrm{Cu}^{\mathrm{u}} \mathrm{M}^{\mathrm{b}}$ & $411 \pm 8$ & 2.96 \\
\hline & Ae. triaristata Willd. $4 \mathrm{x}$ & 28 & $\mathrm{C}^{u} \mathrm{M}^{\mathrm{t}}$ & $513 \pm 10$ & 3.69 \\
\hline & Ae. triaristata Willd. $6 \mathrm{x}$ & 42 & $\mathrm{Cu}^{\mathrm{u}} \mathrm{M}^{\mathrm{t}} \mathrm{M}_{\mathrm{t}_{2}}$ & $727 \pm 13$ & 5.23 \\
\hline & Ae. variabilis Eig & 28 & $\mathrm{CuSv}$ & $479 \pm 6$ & 3.45 \\
\hline & Ae. kotschyi Boiss. & 28 & CuSv & $428 \pm 8$ & 3.08 \\
\hline & $\begin{array}{l}\text { Ae. triuncialis } \mathrm{L} \text {. } \\
\text { ssp. eu-triuncialis } \text { Eig }\end{array}$ & & & & \\
\hline & $\begin{array}{l}\text { var. typica Eig } \\
\text { ssp. orientalis Eig }\end{array}$ & 28 & $\mathrm{CuC}$ & $365 \pm 7$ & 2.63 \\
\hline & var. persica (Boiss.) Eig & 28 & $\mathrm{Cu}^{\mathrm{C}} \mathrm{C}$ & $329 \pm 8$ & 2.37 \\
\hline \multirow[t]{2}{*}{ Cylindropyrum } & Ae. caudata $\mathrm{L}$. & 14 & $\mathrm{C}$ & $161 \pm 4$ & 1.16 \\
\hline & Ae. cylindrica Host & 28 & $\mathrm{CD}$ & $337 \pm 4$ & 2.42 \\
\hline \multirow[t]{2}{*}{ Comopyrum } & Ae. comosa Sibth. et Sm. & 14 & M & $215 \pm 5$ & 1.55 \\
\hline & Ae. uniaristata Vis. & 14 & $M^{u}$ & $219 \pm 5$ & 1.58 \\
\hline Amblyopyrum & Ae. mutica Boiss. & 14 & Mt & $219 \pm 4$ & 1.58 \\
\hline \multirow[t]{3}{*}{ Sitopsis } & Ae. speltoides Tausch. & 14 & $\mathrm{~S}$ & $202 \pm 4$ & 1.45 \\
\hline & Ae. longissima Schw. et Musch. & 14 & $\mathrm{~S}^{1}$ & $224 \pm 3$ & 1.61 \\
\hline & Ae. bicornis (Forsk.) Jaub. et Sp. & 14 & $\mathrm{~S}^{b}$ & $255 \pm 6$ & 1.83 \\
\hline \multirow[t]{9}{*}{ Vertebrata } & $\begin{array}{l}\text { Ae. squarrosa } \mathrm{L} . \\
\quad \text { ssp. eu-squarrosa } \text { Eig }\end{array}$ & & & & \\
\hline & var. typica $\mathrm{L}$. & 14 & $\mathrm{D}$ & $139 \pm 6$ & 1.00 \\
\hline & $\begin{array}{l}\text { var. meyeri Griseb. } \\
\text { ssp. strangulata Eig }\end{array}$ & 14 & $\mathrm{D}$ & $171 \pm 4$ & 1.23 \\
\hline & var. strangulata Eig & 14 & $\mathrm{D}$ & $162 \pm 4$ & 1.17 \\
\hline & Ae. ventricosa Tausch. & 28 & $\mathrm{DM}^{\mathrm{v}}$ & $341 \pm 5$ & 2.45 \\
\hline & Ae. crassa Boiss. $4 \mathrm{x}$ & 28 & $\mathrm{DM}^{\mathrm{cr}}$ & $364 \pm 7$ & 2.62 \\
\hline & Ae. crassa Boiss. $6 x$ & 42 & $\mathrm{DD}^{2} \mathrm{M}^{\mathrm{cr}}$ & $527 \pm 9$ & 3.79 \\
\hline & Ae. vavilovii (Zhuk.) Chenn. & 42 & $\mathrm{DM}^{\mathrm{cr} S \mathrm{p}}$ & $616 \pm 14$ & 4.43 \\
\hline & Ae. juvenalis (Thell.) Eig & 42 & $\mathrm{DCu}^{\mathrm{u}} \mathrm{j}$ & $632 \pm 10$ & 4.55 \\
\hline
\end{tabular}

* The ratio of each species to Ae. squarrosa var. typica.

made among five species or varieties of similar ploidy. Pollen tetrads of these five, including the standard one were smeared side by side on each slide. After permeation of cold $\mathrm{N}-\mathrm{HCl}$ for five minutes, materials were hydrolyzed with $\mathrm{N}-\mathrm{HCl}$ at $60^{\circ} \mathrm{C}$ for five minutes, washed in tap water, stained by buffered Schiff's reagent for four hours at room temperature, immersed three times in potassium metabisulfite solution for 15 minutes each and then embedded in balsam by routine procedure.

Measurement was made by the two-wave length method using Olympus micro- 
spectrophotometer (MSP A-IV). Thirty tetrad nuclei, 10 from each of three slides were measured. All measurements were carried out simultaneously on each slide.

\section{RESULTS}

Nuclear DNA content obtained for all species of Aegilops is summarized in Table 1 in terms of mean, standard error and ratio to that of Ae. squarrosa var. typica. Frequency distributions for DNA content per nucleus of seven strains of nine diploid species of Aegilops with Triticum aegilopoides are illustrated in Fig. 1. An analysis of variance (Table 2-a) shows that significant differences exist among diploid species or varieties and the test of significance of mean DNA content is given in Table 2-b. From these data it is evident that there are considerable intraspecific (Ae. squarrosa; 139 to 171) as well as remarkable interspecific differences in DNA content (157 for $A e$. squarrosa to 255 for Ae. bicornis) in diploid species. It was possible to divide these nine diploids roughly into two groups (Table 2-b), that is, a lower (Ae. squarrosa, Ae. caudata and Ae. umbellulata) and a higher group (Ae. comosa, Ae. uniaristata, Ae. mutica, Ae. speltoides, Ae. longissima and Ae. bicornis).

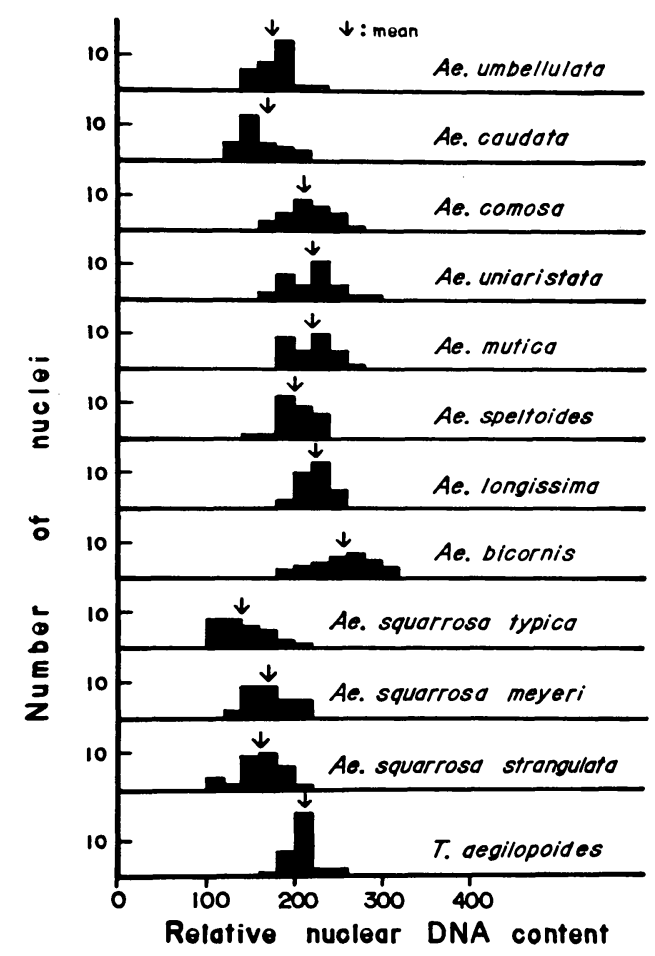

Fig. 1. Frequency distribution of nuclear DNA content in 10 diploid species of Aegilops and Triticum. Value for $T$. aegilopoides was taken from Nishikawa and Furuta (1969). 
Table 2. Analysis of variance and test of significance for nuclear DNA content of eleven varieties of nine diploid species of Aegilops

(a) Analysis of variance

\begin{tabular}{lrrrr}
\hline \multicolumn{1}{c}{ Source } & D.F. & \multicolumn{1}{c}{ S.S. } & M.S. & F-value \\
\hline Species or variety & 10 & 373,314 & 37,331 & $25.33^{* *}$ \\
Replication & 22 & 32,431 & 1,474 & $2.67^{* *}$ \\
Error & 297 & 164,116 & 553 & \\
\hline Total & 329 & 569,861 & & \\
\hline
\end{tabular}

(b) Test of significance on means at $5 \%$ level

\begin{tabular}{lccccccccccc}
\hline \hline \multicolumn{1}{c}{ Species or variety } & Genome & $\bar{X}$ & $\mathrm{D}-t^{*}$ & $\mathrm{C}$ & $\mathrm{D}-\mathrm{s}$ & $\mathrm{D}-m$ & $\mathrm{Cu}$ & $\mathrm{S}$ & $\mathrm{M}$ & $\mathrm{M}^{\mathrm{u}}, \mathrm{Mt}$ & $\mathrm{S}^{1}$ \\
\hline bicornis & $\mathrm{S}$ & 255 & + & + & + & + & + & + & + & + & + \\
longissima & $\mathrm{S}$ & 224 & + & + & + & + & + & + & - & - & \\
mutica & $\mathrm{Mt}$ & 219 & + & + & + & + & + & + & - & - & \\
uniaristata & $\mathrm{M}^{\mathrm{u}}$ & 219 & + & + & + & + & + & + & - & & \\
comosa & $\mathrm{M}$ & 215 & + & + & + & + & + & + & & & \\
speltoides & $\mathrm{S}$ & 202 & + & + & + & + & + & & & & \\
umbellulata & $\mathrm{Cu}$ & 176 & + & - & - & - & & & & \\
squarrosa meyeri & $\mathrm{D}-m$ & 171 & + & - & - & & & & & \\
squarrosa strangulata & $\mathrm{D}-s$ & 162 & + & - & & & & & & \\
caudata & $\mathrm{C}$ & 161 & + & & & & & & & \\
squarrosa typica & $\mathrm{D}-t$ & 139 & & & & & & & & \\
\hline
\end{tabular}

* D- $t, \mathrm{D}-s$ and D- $m$ represent Ae. squarrosa var. typica, strangulata and meyeri, respectively.

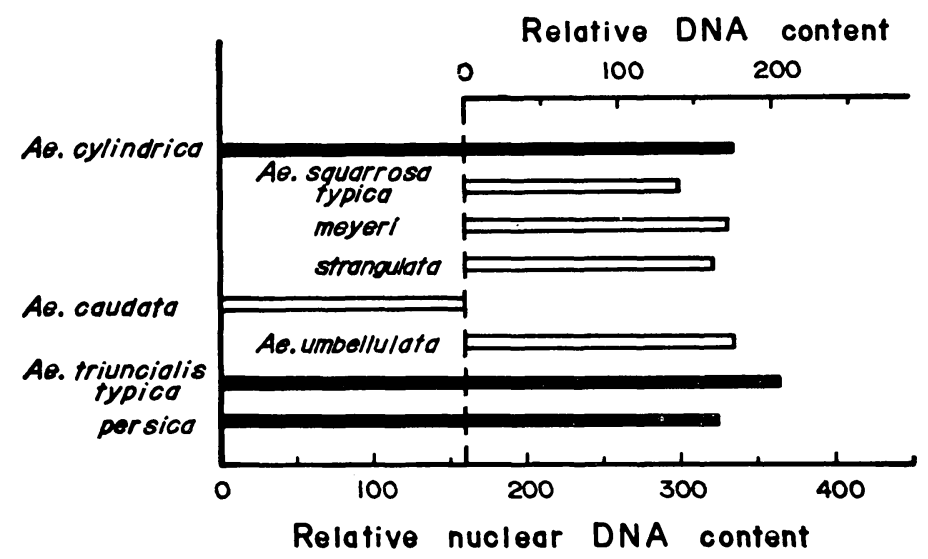

Fig. 2. Histogram for mean nuclear DNA content of Ae. cylindrica and Ae. triuncialis (solid bars) and the expected values (empty bars) which correspond to the sum of DNA content of their parental species, Ae. caudata, Ae. squarrosa or Ae. umbellulata. 
No significant difference was detected between representatives of two subspecies of Ae. triuncialis, although var. typica (365) had a little more DNA than var. persica (329) (Table 1, Fig. 2). DNA content of two tetraploids (Ae. triuncialis and Ae. cylindrica) whose diploid ancestors were definitely confirmed was fully comparable to the sum of that of their respective parental species (Fig. 2).

Six, out of seven tetraploids in section Polyeides, which have one common genome derived from $A e$. umbellulata and the other differentiating of unknown derivation had DNA content specific for each species (Table 3, Fig. 3). Most of the species studied here were represented by only one strain, but data obtained indicated that there are reduced $(A e$. ovata) and augmented types (Ae. triaristata $4 \mathrm{x})$ in addition to unaltered type (Ae. biuncialis and Ae. columnaris). These types are evident when their DNA content is compared with the sum of DNA content of their putative ancestors, $A e$. umbellulata and Ae. comosa or Ae. uniaristata. For example, the DNA content of $A e$. biuncialis (411) was almost equal to the expected DNA value, that is, the sum of $A e$. umbellulata (176) and Ae. comosa (215) or Ae. uniaristata (219) and that of Ae. columnaris (365) approximated the sum (391 or 395) of its diploid ancestors. Ae. triaristata $4 \mathrm{x}$ (513), however, had $31 \%$ more DNA than the expected value (ca. 393), while $A e$. ovata (321) had only about $82 \%$ of that expected. This fact points out that those tetraploids suffered considerable modification in nuclear DNA content after amphiploidization. Statistical difference existed between Ae. variabilis (479) and Ae. kotschyi (428) which have same genome constitution. The latter was nearer to the sum (431 or $400=$ sum of $A e$. umbellulata and Ae. bicornis or Ae. longissima, respectively) of its putative progenitors than the former. This coincides with morphological and karyotypical dissimilarlities between both taxa (Eig 1929, Chennaveeraiah 1960).

With respect to two tetraploid species (Ae. ventricosa and Ae. crassa $4 \mathrm{x}$ ) of section

Table 3. Analysis of variance and test of significance for nuclear DNA content of six tetraploid species belonging to section Polyeides of Aegilops

(a) Analysis of variance

\begin{tabular}{lrrrr}
\hline \multicolumn{1}{c}{ Source } & D.F. & \multicolumn{1}{c}{ S.S. } & M.S. & F-value \\
\hline Species & 5 & 750,959 & 150,192 & $21.38^{* *}$ \\
Replication & 12 & 84,307 & 7,026 & $3.92^{* *}$ \\
Error & 162 & 290,337 & 1,792 & \\
Total & 180 & $1,125,603$ & & \\
\hline
\end{tabular}

(b) Test of significance on means at $5 \%$ level

\begin{tabular}{|c|c|c|c|c|c|c|c|}
\hline Species & Genome & $\bar{X}$ & $\mathrm{Cu} \mathrm{Mo}^{\circ}$ & $\mathrm{Cu}^{\mathrm{u}} \mathrm{M}$ & $\mathrm{Cu}^{\mathrm{u}} \mathrm{M}^{\mathrm{b}}$ & $\mathrm{CuS}^{\mathrm{v}}-k^{*}$ & $\mathrm{CuS}^{\mathrm{v}}-v$ \\
\hline Ae. triaristata & $\mathrm{CuM}^{\mathrm{t}}$ & 513 & + & + & + & + & + \\
\hline Ae. variabilis & $\mathrm{CuSv}^{-v}$ & 479 & + & + & + & + & \\
\hline Ae. kotschyi & $\mathrm{CuSv}^{\mathrm{u}} k$ & 428 & + & + & - & & \\
\hline Ae. biuncialis & $\mathrm{Cu}^{\mathrm{u}} \mathrm{M}^{\mathrm{b}}$ & 411 & + & + & & & \\
\hline Ae. columnaris & $\mathrm{Cu}^{\mathrm{u}} \mathrm{c}$ & 365 & + & & & & \\
\hline Ae. ovata & $\mathrm{Cu}^{\mathrm{M}} \mathrm{o}$ & 321 & & & & & \\
\hline
\end{tabular}

* $\mathrm{CuS}^{\mathrm{v}}-k$ and $\mathrm{Cu}^{\mathrm{u}}{ }^{\mathrm{v}}-v$ represent $A e$. kotschyi and $A e$. variabilis, respectively. 


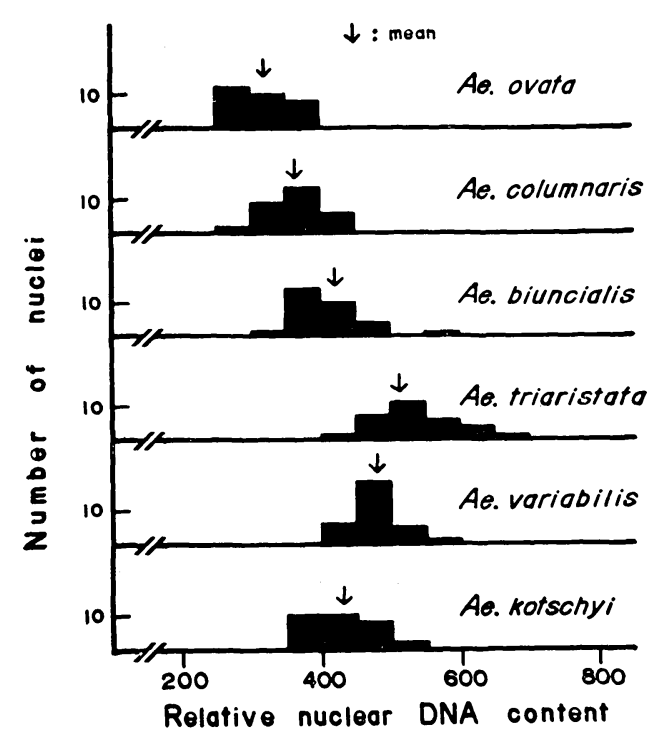

Fig. 3. Frequency distribution of nuclear DNA content in six tetraploid species belonging to section Polyeides of Aegilops.

Vertebrata, a variance analysis did not reveal significant difference between these two species and among replications. The expected value (ca. $372=$ sum of $A e$. squarrosa and $A e$. comosa or Ae. uniaristata) was nearer to that (364) of Ae. crassa $4 \mathrm{x}$ than $A e$. ventricosa (341). Considering the intraspecific variation in Ae. squarrosa, one of the ancestors, the observed value of $A e$. ventricosa was rather in agreement with the previous works that this tetraploid was derived from Ae. squarrosa and Ae. uniaristata (Matsumoto and Kondo 1942, Matsumoto et al. 1957, Chennaveeraiah 1960).

At the hexaploid level, Ae. triaristata 6x (727) had the highest DNA content among all species and was almost equal to the expected value $(732=$ sum of Ae. triaristata $4 \mathrm{x}$ and $A e$. uniaristata). A significant difference at the $1 \%$ level was found between $A e$. crassa $6 \mathrm{x}$ (527) and Ae. vavilovii (616). The DNA content of these species was almost equal to sum of those of respective parental species, Ae. crassa $6 \mathrm{x}$ : Ae. crassa $4 \mathrm{x}$ and Ae. squarrosa, Ae. vavilovii: Ae. crassa $4 \mathrm{x}$ and Ae. longissima (Chennaveeraiah 1960). The observed value (632) of $A e$. juvenalis did not coincide with the expected value.

\section{DISCUSSION}

Cytophotometrical determination and comparison of DNA content per cell or nucleus have become an efficient tool in understanding species relationship in various plants and animals. One of the results obtained in this study is that there are not only remarkable interspecific but also considerable intraspecific variations with regard to DNA content per nucleus in nine diploid species of Aegilops. Comparable findings of interspecific variation in nuclear DNA content of diploid plants are relatively frequent in literature (Tulipa: Southern 1967, Oryza: Katayama 1967, Pinus: Miksche 1967, Allium: 
Jones and Rees 1968, Chrysanthemum: Dowrick and El Bayomi 1969, Vicia: Chooi 1971 and Lotus: Cheng and Grant 1973). It should be pointed out that those cited above reported continuous variation in DNA content of the nucleus. All but Allium have the same chromosome number within each genus. This is exactly the case with genus Aegilops. In diploids of Aegilops, differentiation of species is associated with a change in DNA content but not with a change of chromosome number. Bennett ahd Smith (1971) and Bullen and Rees (1972) reported, however, no significant differences among 15 varieties of seven diploid species of Hordeum and among six diploids of Avena, respectively. It is important to point out that Aegilops is in contrast to Hordeum and Avena which have evolved without quantitative change of nuclear DNA.

A reduction of DNA content was reported in polyploids of various genera of plants, but any polyploids having more DNA content than the sum of that of the ancestors were not known (Furuta et al. 1974). In Aegilops, those polyploid species whose diploid parents have been unequivocally identified have a DNA content comparable to sum of their parents', while in polyploid species carrying a common genome and a differentiating genome, some are more and others less than the sum of the related genomes in DNA content of nucleus. Nuclear DNA content of Ae. triaristata $4 \mathrm{x}$ and $A e$. juvenalis was considerably more than the expected value. It is suggested that either these two polyploids might have acquired more chromosomal DNA to stabilize their genetical and cytological systems or their proposed parents may have undergone a change in nuclear DNA content.

Although Kihara (1954) symbolized Ae. variabilis and Ae. kotschyi with the common genome formula $\left(\mathrm{C}^{\mathrm{u}} \mathrm{S}^{\mathrm{v}}\right)$, the present author (unpublished) observed considerably complicated chromosome pairing in their $F_{1}$ 's. Difference in DNA content between these taxa as shown in this experiment probably reflects a difference in chromosome structure.

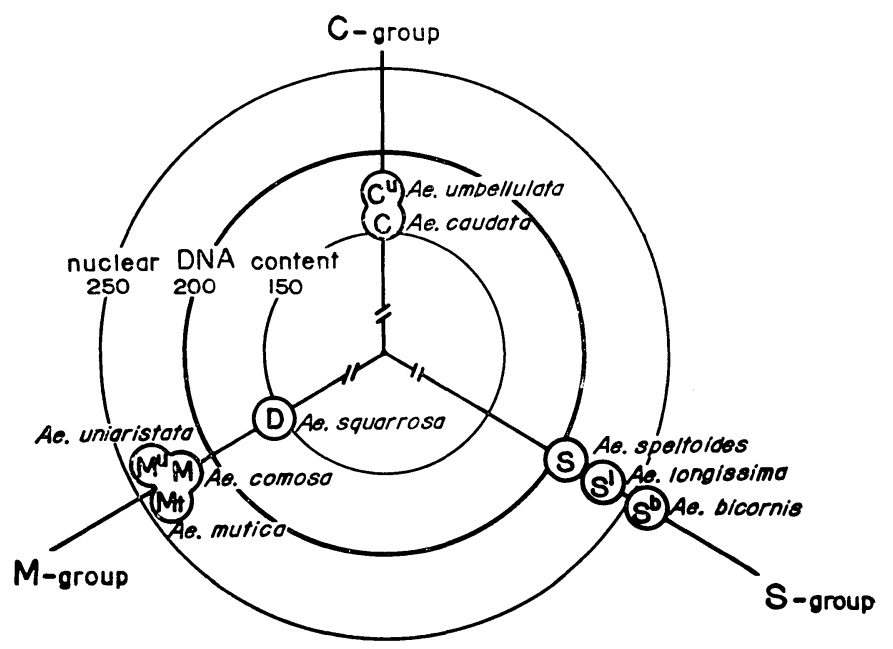

Fig. 4. Species relationship of diploid species of Aegilops with reference to DNA content. C, M and S grouping was based on Kihara (1954). 
Kihara (1954) classified twelve diploid species (nine genome types) of Aegilops into three groups based on chromosome pairing intensity. The relation of DNA content to Kihara's grouping is picturized in Fig. 4. Two members of the $\mathrm{C}$ group, $A e$. caudata and Ae. umbellulata belong to the lower DNA group as mentioned in the previous section and are almost equal to each other in DNA content. Sears (1948) and Chennaveeraiah (1960) found differences between Ae. caudata and Ae. umbellulata in morphology, karyotype and chromosome structure, whereas these two species represented similarity in DNA content which is in accordance with Kihara's grouping. Three species of section Sitopsis (S group) are in a higher DNA group and show continuous variation like other characters. In the M group, Ae. uniaristata, Ae. comosa and $A e$. mutica cluster in a higher group and are apart from Ae. squarrosa located in the lower group. This fact is in agreement with morphological distinctions between Ae. squarrosa and others and supports the grouping of Zohary and Feldman (1962). Although Chennaveeraiah (1960) pointed out that Ae. uniaristata karyotypically differed from $A e$. comosa, these two species were comparable to each other in DNA content.

Based on limited data present here, it seems significant to make some speculations as to the relation of DNA content of each genomes to their destiny. Three diploid species which are remotely related and whose species are diagnostic to one another, Ae. squarrosa, Ae. caudata and Ae. umbellulata not only belonging to the lower DNA group, but are nearly equal in the amount of DNA in their nuclei. On the other hand, these species are known to be donors of the unaltered or pivotal genome to polyploid relatives as refered to by Zohary and Feldman (1962) and Zohary (1965). Thus, there seems to be a coincidence between a lower DNA content of the nucleus and stability of genome after polyploidization. In contrast to this the modified genomes of polyploid species of Aegilops were introduced from diploid species that belonged to the higher DNA group. These diploids are Ae. comosa and Ae. uniaristata on one hand and $A e$. speltoides, Ae. longissima and Ae. bicornis on the other, which are closely related to one another, respectively. Moreover, there are close relatives of these species, which were regarded as subspecies or variety rank by Kihara (1954), that is, Ae. heldreichii to $A e$. comosa, Ae. aucheri to Ae. speltoides and Ae. sharonensis to Ae. longissima, respectively. These facts may suggest that those species that belonged to the higher DNA group were subjected in the course of evolution to a change of DNA content of the nucleus in polyploid as well as in diploid level. Instability of the genomes with the higher DNA content may be a reasonable explanation for the fact that there is no tetraploid species that consists of genomes of the higher DNA group. Out of nine tetraploids, Ae. triuncialis and Ae. cylindrica consists of two genomes belonging to the lower DNA group; the other tetraploids consist of one genome from the lower and another from the higher DNA group. These facts suggest that tetraploid species of two genomes from the higher DNA group might presumably be selectively disadvantageous.

Finally, it is surprising that the nuclear DNA content of Ae. mutica is so similar to that of Ae. speltoides as are other cytological characters (Chennaveeraiah 1960; Jones and Majusu 1968). 


\section{ACKNOWLEDGMENT}

The author is indebted to Dr. M. Tanaka, Kyoto University, for his supply of all materials used in this experiment. The author's thanks are also due to Dr. K. Nishikawa, Gifu University and Dr. T. E. Haus of the Department of Agronomy, Colorado State University, for their kindness in reading the manuscript and making valuable suggestions.

\section{SUMMARY}

Nuclear DNA content of pollen tetrads of all species of the genus Aegilops were measured microspectrophotometrically.

1) Nine diploid species have a species specific amount of DNA and are divided into a lower or a higher DNA group based on nuclear DNA content. The speciation in Aegilops diploids is associated with a change in DNA content, but not with a change of chromosome number.

2) Significant differences were found among three varieties of Ae. squarrosa.

3) Two tetraploids (Ae. triuncialis and Ae. cylindrica) whose parentage has been confirmed were comparable to the sum of parents in DNA content of the nucleus.

4) No difference between two subspecies of Ae. triuncialis was found, but there was significant difference between $A e$. variabilis and Ae. kotschyi which have the same genome constitution.

5) In polyploid species whose diploid ancestors have not been clearly identified, because of modification of the genomes involved, some showed no change, some reduction and still others an increase in DNA content of the nucleus as compared with the putative ancestors.

\section{LITERATURE CITED}

Bennett, M. D., and J. B. Smith, 1971 The nuclear DNA content of several Hordeum genotypes. Can. J. Genet. Cytol. 13: 607-611.

Bullen, M. R., and H. Rees, 1972 Nuclear variation within Avenae. Chromosoma 39: 93-100.

Cheng, R. I-J., and W. F. Grant, 1973 Species relationships in the Lotus corniculatus group as determined by karyotype and cytophotometric analysis. Can. J. Genet. Cytol. 15: 101-115.

Chennaveeraiah, M. S., 1960 Karyomorphologic and cytotaxonomic studies in Aegilops. Acta Horti Gotoburgensis 23: 85-178.

Chooi, W. Y., 1971 Variation in nuclear DNA content in the genus Vicia. Genetics 68: 195-211. Dowrick, G. J., and A. S. El-Bayoumi, 1969 Nucleic acid content and chromosome morphology in Chrysanthemum. Genet. Res., Camb. 13: 241-250.

Eig, A., 1929 Monographisch-Kritische Ubersicht der Gattung Aegilops. Repot. Spec. Nov. Reg. Veget. Beih. 55: 1-228.

Furuta, Y., K. Nishikawa, and T. Tanino, 1974 Stability in DNA content of AB genome component of common wheat during the past seven thousand years. Japan. J. Genetics 49: 179-187.

Jones, J. K., and B. N. Majisu, 1968 The homoeology of Aegilops mutica chromosomes. Can. J. Genet. Cytol. 10: 620-626. 
Jones, R. N., and H. Rees, 1968 Nuclear DNA variation in Allium. Heredity 23: 591-605.

Katayama, T., 1967 Relative amounts of deoxyribonucleic acid (DNA) per nucleus of diploid species in Oryza. Japan. J. Breed. 17: 177-181.

Kihara, H., 1954 Considerations on the evolution and distribution of Aegilops species based on the analyser-method. Cytologia 19: 336-357.

Kihara, H., and M. Tanaka, 1970 Addendum to the classification of the genus Aegilops by means of genome-analysis. Wheat Information Service 30: 1-2.

Matsumoto, K., and N. Kondo, 1942 Two new amphidiploids in Aegilops. (in Japanese) Japan. J. Genetics 18: 130-133.

Matsumoto, K., M. Shimotsuma, and M. Nezu, 1957 The amphidiploid M ${ }^{u} \mathrm{M}^{\mathrm{u} D D}$ and its hybrids with Aegilops ventricosa. Wheat Information Service 5: 12-13.

Miksche, J. P., 1967 Variation in DNA content of several gymnosperms. Can. J. Genet. Cytol. 9: $717-722$.

Nakai, Y., 1973 Isozyme variations in Aegilops and Triticum, II. Esterase and acid phosphatase isozymes studied by the gel isoelectrofocusing method. Seiken Zihō 24: 45-73.

Nakai, Y., and K. Tsunewaki, 1971 Isozyme variations in Aegilops and Triticum. I. Esterase isozymes in Aegilops studied using the gel isoelectrofocusing method. Japan. J. Genetics 46: $321-336$.

Nishikawa, K., and Y. Furuta, 1969 DNA content per nucleus in relation to phylogeny of wheat and its relatives. Japan. J. Genetics 44: 23-29.

Sears, E. R., 1948 The cytology and genetics of the wheat and their relatives. Advances in Genetics 2: 239-270.

Sears, E. R., 1956 The transfer of leaf-rust resistance from Aegilops umbellulata to wheat. Brookhaven Symposia in Biology 9: 1-22.

Senjaninova-Korczagina, M., 1932 Karyosystematical investigation of the genus Aegilops L. Bull. Appl. Bot. Genet. Plant Breed. Ser. 2: 1-90.

Southern, D. I., 1967 Species relationships in the genus Tulipa. Chromosoma 23: 80-94.

Zhukovsky, P. M., 1928 A critical-systematical survey of the species of the genus Aegilops L. Bull. Appl. Bot. Genet. Flant Breed. 18: 417-609.

Zohary, D., 1965 Colonizer species in the wheat group. In The Genetics of Colonizing Species (Barker, H. G., and G. L. Stebbins eds.) 403-423. Academic Press, New York.

Zohary, D., and M. Feldman, 1962 Hybridization between amphidiploids and the evolution of polyploids in the wheat (Aegilops-Triticum) group. Evolution 16: 44-61. 